\title{
Correction to: Day case laparoscopic cholecystectomy at Kilimanjaro Christian Medical Centre, Tanzania
}

\author{
Imogen Cullen ${ }^{1,5}$ (1) Fadlo Shaban ${ }^{2} \cdot$ Oroog $\mathrm{Ali}^{2} \cdot$ Matthew Breckons $^{3} \cdot$ Kondo Chilonga $^{4} \cdot$ Daudi Wapalila ${ }^{4}$. \\ Jamil Suleiman ${ }^{4} \cdot$ Mercy Elinisa $^{4} \cdot$ Bronwyn Woodburn $^{1} \cdot$ Richard Walker $^{2,3} \cdot$ Liam Horgan $^{2}$
}

Published online: 21 January 2021

(c) The Author(s) 2021

\section{Correction to: Surgical Endoscopy https://doi.org/10.1007/s00464-020-07914-9}

This article was updated to correct the spelling of Jamil Suleiman's name in the author listing and Disclosures.

Open Access This article is licensed under a Creative Commons Attribution 4.0 International License, which permits use, sharing, adaptation, distribution and reproduction in any medium or format, as long as you give appropriate credit to the original author(s) and the source, provide a link to the Creative Commons licence, and indicate if changes were made. The images or other third party material in this article are included in the article's Creative Commons licence, unless indicated otherwise in a credit line to the material. If material is not included in the article's Creative Commons licence and your intended use is not permitted by statutory regulation or exceeds the permitted use, you will need to obtain permission directly from the copyright holder. To view a copy of this licence, visit http://creativecommons.org/licenses/by/4.0/.

Publisher's Note Springer Nature remains neutral with regard to jurisdictional claims in published maps and institutional affiliations.
The original article can be found online at https://doi.org/10.1007/ s00464-020-07914-9.

Imogen Cullen

imogenlouisacullen@gmail.com

1 Newcastle University, Newcastle upon Tyne, United Kingdom

2 Northumbria Healthcare NHS Foundation Trust, Newcastle upon Tyne, United Kingdom

3 Institute of Health and Society, Newcastle University, Newcastle upon Tyne, United Kingdom

4 Kilimanjaro Christian Medical Centre, Kilimanjaro, Tanzania

5 The Medical School, Newcastle University, Framlington Place, Newcastle upon Tyne NE2 4HH, United Kingdom 